\title{
Isolation of fungi from various habitats and their possible bioremediation
}

\author{
Farazimah Yakop, Hussein Taha and Pooja Shivanand* \\ Environmental and Life Sciences Programme, Faculty of Science, Universiti Brunei Darussalam, Jalan Tungku Link BE 1410, Brunei Darussalam
}

\begin{abstract}
Fungi are the most diverse and adaptable group of living organisms. The literature highlights that colonization density and fungal diversity can be affected by factors such as salinity, $\mathrm{pH}$, temperature, altitude and availability of nutrients. The present article discusses isolation and characterization of fungi from different ecosystems like forests, mangroves and coastal areas. Fungal interaction with ecosystems is reported to play an important role in the biodiversity, survivability, propagation and productivity of plants. Fungi have established a beneficial association with numerous hosts and have the capability to degrade environmental pollutants such as hydrocarbons and by-products. Hence, fungi and fungal products like extracellular hydrolytic and lignin-degrading enzymes, and surfactants offer eco-friendly and cost-effective strategies to address pollution, especially with respect to bioremediation of oil spills and polyaromatic hydrocarbons.
\end{abstract}

Keywords: Bioremediation, fungi, habitats, hydrocarbon degradation.

FUNGI are diverse organisms consisting of seven recognized phyla: Ascomycota, Basidiomycota, Blastocladiomycota, Chytridiomycota, Glomeromycota, Microsporidia and Neocallimastigomycota ${ }^{1}$. They are ubiquitous, occurring in various types of habitats. Since 1860, many fungi have been isolated from various habitats: grasslands, tropical forests, polar regions, deserts and coastal areas. Fungi are considered as one of the most adaptable groups of organisms and also as essential soil microbial constituents $^{2,3}$. They are essential components of the soil, contributing to nutrient availability and supporting the propagation of ecosystems such as mangroves. They are decomposers of organic matter such as wood, stem and leaf, and also function as plant symbionts in ecosystems, playing an important role in ecological and biogeochemical processes. Thus, fungi contribute to the degradation of organic matter in the ecosystems ${ }^{1,2,4,5}$. The frequency and diversity of fungi vary from place to place, depending on the physical, chemical and biological factors of their habitat ${ }^{6}$.

Apart from playing a key role in the ecosystems, fungi are also beneficial for industrial and other uses such as

*For correspondence. (e-mail: pooja.shivanand@ubd.edu.bn) pigment and drug production $^{7-9}$, food industry ${ }^{10}$ and bioremediation $^{11,12}$. In this article, the diversity of these fungi and their isolation from various habitats as well as their bioremediation capabilities are discussed.

\section{Isolation and identification of fungi}

Isolation of mycorrhizal fungi involves two methods. First, soil samples from the rhizosphere of the host plants are suspended in water and sieved through meshes of various size. Fungal infection of roots was observed under a microscope, and the soil suspension is examined for spores $^{13-15}$. In the second method, soil samples were serially diluted with sterile distilled water at various concentrations $\left(10^{-1}\right.$ to $\left.10^{-7}\right)$ to be used as inocula for the isolation of fungi. They can be isolated using different growth media such as mycological broth agar, potato dextrose agar, Sabouraud dextrose agar, Czapek's dox agar and malt extract agar ${ }^{2,4,5}$. Most studies prefer potato dextrose agar medium to isolate fungi from environmental samples ${ }^{6,16-18}$.

Isolation of endophytic fungi is slightly different compared to mycorrhizal fungi as fungal endophytes can only be found within the plant tissues. The two most common methods are scraping method and fragment plating method. In the scraping method, the sterilized plant material is cut half longitudinally and the pith is scraped with a sterile scalpel. The presence of hyphae is determined under a microscope. This method is limited only to mature plants. However, in fragment plating method, sections of sterilized plant materials are placed on prepared media plates and incubated until fungal growth is observed. Later, the tips of the fungal hyphae are removed and placed in mycological media ${ }^{19-24}$

Mycological media should contain an antibiotic (such as streptomycin or chloramphenicol) to suppress bacterial growth. Cultures are incubated at $25-30^{\circ} \mathrm{C}$ at different time periods, depending on the rate of fungal growth. Fungal colonies with morphological differences are subcultured on fresh agar plates to ensure the isolation of pure cultures ${ }^{2,4,17,25,26}$.

Initially, fungal isolates acquired from the samples are identified based on morphology and microscopic examination. Morphological characteristics could be identified by the colour and septation of spores, pigmentation and the fruiting body with reference to identification keys. 
Monographs used to identify the morphology of fungi are Standard Manuals of Marine Mycology, the Higher Fungi, Compendium of Soil Fungi and Genera of Hyphomycetes $^{2,25,27}$.

The micro-features of pure culture can be identified by semi-permanent microscopic preparations of fungi using lactophenol cotton blue stain. A drop of lactophenol cotton blue stain is placed on a clean slide before transferring a small tuft of fungus with a sterilized inoculating loop. Then the slides are gently heated to release air bubbles, if any, on the glass cover and later observed under the microscope with oil immersion objective ${ }^{6,17,25,28,29}$.

Identification of fungi can also be done genetically and is often used to confirm the initial morphological identification. The most common marker used for species identification and phylogenetic analysis is the ITS (internal transcribed spacer) region.

\section{Isolation of fungi from forest ecosystems}

Different species of soil fungi are found in forest areas across the world. The most common fungi in forest soils are Aspergillus Micheli, Penicillium Link, Trichoderma Pers. and Fusarium Link. They have been found in various types of forest soils such as yellow-brown forest soil, raw calcareous soil, yellow soil, red soil, mountainmeadow soil and brown forest soil ${ }^{30}$, as well as from dark brown forest soil, brown coniferous forest soil, mountain grass forest soil and mountain tundra soil ${ }^{31}$.

Several studies have discussed the isolation and characterization of various strains of fungi from different forests around the world. Isolation of Trichoderma, Fusarium, Acremonium Link, Penicillium and Paecilomyces Samson from Brazilian Savannah and Atlantic rainforest has been reported ${ }^{32}$. In Nanga Merit Forest, Sarawak, Malaysia, isolates of Penicillium and Streptomyces Waksman \& Henrici have been characterized ${ }^{33}$. Paecilomyces marquandii (Massee) S. Hughes, Aspergillus flavus Link, A. fumigatus Fresenius, Mucor hiemalis Wehmer, Penicillium sp., Cladosporium herbarum (Pers.) Link, Trichosporiella cerebriformis (G.A. de Vries \& Kleine-Natrop) W. Gams, Mortierella sp. Coem., Syncephalastrum recemosum Cohn and Cunninghamella echinulata (Thaxt.) Thaxt. ex Blakeslee were identified from Bhadra Wildlife Sanctuary in the Western Ghats, India, comprised of dry and moist deciduous, semi-evergreen and evergreen forests ${ }^{34}$. Another study carried out in the same area by Banakar and Thippeswamy ${ }^{35}$ revealed other fungal species, such as Chaetomium globosum Kunze, Thelephora terrestris Ehrh., Humicola sp. Traaen, Talaromyces sp. C.R. Benj., Trametes versicolor (L.) Lloyd, Trametes hirsuta (Wulfen) Lloyd, Phanerochaete sordida (P. Karst.) J. Erikss. \& Ryvarden, Lenzites betulina (L.) Fr., Pleurotus ostreatus (Jacq.) P. Kumm., Stereum ostrea (Blume \& T. Nees) Fr. and Phanerochaete chrysosporium Burds.

\section{Isolation of fungi from mangroves}

According to Behera et ll. $^{2}$, mangrove forests are biodiversity hotspots for marine fungi. Mangroves signify intermediate vegetation sandwiched by land and sea, which is growing in waterlogged soil with lack of oxygen. The mangroves soil substrata are generally firm to soft mud with aerial roots known as pneumatophores which emerge from substratum to supply air ${ }^{36}$. Soil is among the essential habitats for microorganisms such as bacteria, fungi, nematodes, etc. and also a general reservoir for wind-dispersed fungal spore ${ }^{4}$.

Gupta $^{13}$ reported fungal diversity of different mangrove areas with varying salinity. There were 45 fungi isolated representing 5 genera (Scutellospora C. Walker \& F. E. Sanders, Glomus Tul. \& C. Tul., Gigaspora Gerd. \& Trappe, Entrophospora R.N. Ames \& R.W. Schneid. and Acaulospora Gerd. \& Trappe). Majority of fungi that were found in low salinity areas belonged to the genus Glomus, and the presence of two Glomus species [Glomus intraradices N.C. Schenck \& G.S. Sm. and G. geosporum (T.H. Nicolson \& Gerd.) C. Walker] in highsalinity areas suggests the possibility of habitat adaptation to salt tolerance ${ }^{13}$. Li et al ${ }^{37}$ studied the endophytic communities in four different mangroves species in China and found that overall colonization frequency on the four host trees varied from $24 \%$ to $33 \%$. Colonization was also seen to be higher in twigs compared to leaves. Three hundred and one fungal isolates were obtained from various samples and ITS sequencing indicated that Phomopsis Sacc. \& Roum., Phyllosticta Pers., Xylaria Hill ex Schrank, Leptosphaerulina McAlpine and Pestalotiopsis Steyaert were dominant in all host species.

The fungal colonization in grey mangroves, Avicennia marina (Forssk.) Vierh. of Red Sea, Saudi Arabia has been studied. Six samples were collected and 145 species were identified. Ascomycota was dominant (76-85\%) in all samples followed by Basidiomycota (14-24\%). The prevalence of Ascomycota in mangroves areas is expected as their lignocelluloses cleaving capabilities are important in areas that are rich in lignin and cellulose, and these fungi would allow the substrates to enter the food web. Aspergillus and Schizosaccharomyces Lindner were found to dominate the soil areas ${ }^{1}$.

\section{Isolation of fungi from coastal areas}

Fungi are known to exist in marine environments since the early times ${ }^{38}$. The ocean reflects a great reservoir of biodiversity. The marine environment is exceptionally complex and comprises a broad variety of fungal diversity $^{39,40}$. Marine fungi are a taxonomically diverse group, developing in many different habitats within the marine ecosystems, including sea water, corals, algae, marine sediments, etc. ${ }^{41,42}$. These marine fungi can be sub-divided 
into two groups: (1) obligate or residents, and (2) facultative or transient fungi. Obligate marine fungi grow and sporulate exclusively in marine or estuarine environments whereas facultative marine fungi inhabit terrestrial or freshwater habitats, but are capable of growing and sporulating in marine environments ${ }^{41}$. Marine-derived fungi have been found in several places such as sediment, sponges, algae, fish, deep sea and mangrove wood ${ }^{43}$. The interest in marine ecology has also increased worldwide. Several substrata in marine environments are good sources for the detection of fungi ${ }^{38}$. Marine fungi have numerous ecological roles such as degradation of biota, provision of chemical protection, pathogenicity, symbiosis and impact on various holobiont groups ${ }^{42}$. Some marine fungi are key decomposers of organic matter, and others are involved in the denitrification process ${ }^{41}$ and hence are considered as a source of industrial enzymes ${ }^{44}$.

Beena et $a l .{ }^{45}$ carried out a study on the diversity of fungi from the coastal sand dunes in India, and isolated 38 species from 5 genera (Scutellospora, Glomus, Gigaspora, Sclerocystis Berk. \& Broome and Acaulospora) with Glomus mosseae (T.H. Nicolson \& Gerd.) Gerd. \& Trappe being the most dominant. Séne et al. ${ }^{15}$ studied the diversity of ectomycorrhizal fungi in Coccoloba uvifera (L.) L. mature trees, and found 8 species colonizing the sporocarps and sclerotia whereas 15 species were found on the root tips, with the seedlings sharing 14 of these taxa. Scleroderma bermudense Coker, Russula cremeolilacina Pegler and Thelephoraceae were dominant. $S$. bermudense had the potential to form a common mycorrhizal network between the mature trees and seedlings, for increasing the survival chances of the seedlings.

Parveen et $a l .^{46}$ explored the fungal diversity in Mahanadi River, India. There were 31 fungal species isolated, with Aspergillus niger Tiegh. being the most prominent. Another study in 2016 had isolated 8 fungal genera ( $A s$ pergillus, Penicillium, Thielavia Zopf, Fusarium, Emericella Berk., Cladosporium Link, Scytalidium Pesante and Alternaria Nees) from Masturah, Saudi Arabia ${ }^{47}$. Most isolated fungi showed significant growth on petroleum media and hence have the potential for biodegrading crude oil-based substances. Since 1957, the Japanese Antarctic Research Expedition has isolated 76 fungal species from the Syowa Station, East Antarctica. Majority of these fungi were Ascomycota and Basidiomycota. They were able to survive in harsh conditions such as low temperatures and lack of nutrients ${ }^{48}$.

\section{Isolation of mycorrhizal fungi}

Fungi that form localized hyphae interfaces have synchronized development with the host plants and benefit the host plants via nutrient transfer are known as mycorrhizae $^{49}$. The most common types of these symbiotic plant-fungus relationships are ectomycorrhizal (ECM) and arbuscular mycorrhizal (AM). ECM is characterized by the formation of a fungal coating on the root surfaces and of hyphal network penetrating between the cortical cells and endodermis, known as Hartig net ${ }^{50}$. This type is usually associated with coniferous and deciduous trees. However, AM is typically associated with herbaceous plants and grasses, and is characterized by the formation of arbuscules within the root cortical cells ${ }^{51,52}$.

These mycorrhizal symbioses enhance plant growth by allowing the soil to be more efficiently utilized, resulting in more uptake of nutrients such as nitrogen and phosphorus, as well as increasing the plant defence mechanism against natural stresses. Nitrogen plays an important part in plant morphology, photosynthesis, formation of nucleic acids and enzymes, whereas phosphorus is needed for cell division, reproduction and metabolism ${ }^{51}$. In return, the fungi benefit from these photosynthesizing plants as the fungi have direct access to the carbohydrates translocated from the leaves into the roots.

The mycoheterotrophic relationship of three common shrubs of the family Pyroleae found on the northern side of Mt Fuji, Japan, with ECM fungi was studied. Pyrola alpina H. Andres, P. incarnata (DC.) Freyn and Orthilia secunda L. were found to have shared similar mycobionts with the surrounding trees, Larix kaempferi (Lamb.) Carr., Abies veitchii Lindley and Betula ermanii Cham, but at different levels. P. incarnata shared almost $70 \%$ mycobionts with the surrounding trees, whereas $P$. alpina and $O$. secunda shared $32 \%$ and $15 \%$ respectively. $O$. secunda was exclusively associated with Wilcoxina sp. Chin S. Yang \& Korf, an ECM fungus, suggesting an independent mycorrhizal association. A more diverse community of ECM fungi was found in the other two Pyrola species, with a higher percentage of shared mycobionts $^{53}$.

Some orchid plants from the forests in Thailand, particularly Aphyllorchis montana Rchb. f, A. caudate Rolfe ex Downie and Cephalanthera exigua Seidenf. were found to have mycoheterotrophic association with ECM fungi. A. montana and A. caudata showed a diverse ECM community, majority of which were Russulaceae and Thelephoraceae. The latter was also found predominantly in $C$. exigua $(65 \%)$, but the same orchid species did not show high ECM diversity as in the other two species, which could be due to its short roots ${ }^{54}$.

de Souza and Freitas ${ }^{55}$ compared AM fungi of an exotic invasive plant, Prosopis juliflora (Sw.) DC. and a native plant, Mimosa tenuiflora (Willd.) Poir. that grow in the tropical seasonal dry forest in Brazil. In both plants, significant differences were observed in fungal composition as well as in the soil chemical factors such as soil $\mathrm{pH}$, total organic carbon, total nitrogen and availability of phosphorus. A total of 29 species of AM fungi were found in all of the soil samples with the orders Glomerales $(44.8 \%)$ and Gigasporales $(41.4 \%)$ and the genus 
Funneliformis C. Walker \& A. Schüßler being the most prevalent. The soils where $P$. juliflora developed had higher chemical factors, but only consisted of AM fungi from the orders Diversisporales, Gigasporales and Glomerales. The soils where $M$. tenuiflora developed also had AM fungi from the same orders but also with the order Archaeosporales, making the AM community more diverse.

Swietenia macrophylla King seedlings and mature trees growing in a tropical rainforest in Mexico, were studied for their AM fungal communities. Almost 23 fungi were isolated and classified into 4 genera. The diversity of AM fungi in the mature trees composed of Glomus (52.3\%), Acaulospora (38\%), Ambispora C. Walker, Vestberg \& A. Schüssler and Gigaspora (4.7\% each). Acaulospora $(63.6 \%)$ and Glomus $(36.3 \%)$ were isolated from the seedlings ${ }^{56}$. Lang et al. $^{57}$ studied the diversity of mycorrhizal species in mixed deciduous forests in Germany. A total of 130 ECM fungal species were detected on the root tips of host plants (Fagus sp. L., Tilia sp. L. and Carpinus sp. L.). These species colonized $92.8 \%$ of the root tips, and AM fungi were abundant in the roots of Fraxinus sp. L. and Acer sp. L.

Souza and Rodrigues studied the diversity of AM fungi in three mangrove species (Acanthus ilicifolius L., Excoecaria agallocha L. and Rhizophora mucronata Lam.) from two mangrove forests in India and during different seasons (pre-monsoon, monsoon and post-monsoon). A total of $11 \mathrm{AM}$ fungi from five genera (Rhizophagus P.A. Dang., Glomus, Funneliformis, Racocetra Oehl, F.A. Souza \& Sieverd. and Acaulospora) were isolated from all sites and during all seasons. Species richness and spore density were recorded highest in pre-monsoon season and lowest in monsoon season. The high spore density in pre-monsoon season could be explained by soil temperature, as higher temperature favours AM fungal sporulation, or by other factors ${ }^{58}$. Studies of ECM fungi from mangroves are limited as the fungal communities in mangroves are typically $\mathrm{AM}^{59}$.

In a study, coastal sands and reclamation sites in Iceland were examined for AM fungal abundance ${ }^{60}$. On the coastal sand plain, AM fungi were not found on the barren sand, while some were discovered in a natural old dune system and in the reclamation sites of Leymus arenarius (L.) Hochst. However, the older reclamation site had a higher number of AM fungi compared to new sites. The same was observed on the volcanic island of Surtsey. Different AM inocula of $L$. arenarius revealed that indigenous AM fungi were able to improve the growth of seedlings ${ }^{60}$. A study was carried out on a New Zealand dune, where root samples of Spinifex sericeus R.Br. were collected $^{61}$. A total of 22 AM fungal operational taxonomic units (OTUs) were identified and classified into 7 genera; the dominant genera were Rhizophagus and Racocetra.

The association of ECM fungi and trees in relation to environmental stress was examined, where environmental stress had reduced the growth of Pinus muricata D. Don. A total of 82 species were isolated, and preferential root colonizers such as Suillus tomentosus (Kauffman) Singer and Russula brunneola Burl. were found on pygmy and nonpygmy host plants respectively. It was also found that the trees from the more stressful environment were preferentially colonized by ECM fungi with more carbonintense foraging strategies ${ }^{62}$.

\section{Isolation of endophytic fungi}

Endophytic fungi live within plant tissues, such as leaves, twigs, branches and roots ${ }^{63}$. These fungi produce metabolites that generally cause no harm to the plants, but can increase the survival fitness of the hosts ${ }^{63,64}$. Differences in the species composition of fungal endophytes can be observed in trees with different growth rates, as shown in a study where 43 fungi were identified from 360 twigs of Pinus sylvestris L. (Scots pine) in northern Spain ${ }^{65}$. The most abundant fungi were from the classes Dothideomycetes and Sordariomycetes. The endophytic community between fast- and slow-growing pines was found to be different, with Phoma herbarum Westend. occupying the twigs of fast-growing trees while Hypocrea lixii Pat. was associated with the slow-growing trees ${ }^{65}$.

Rojas-Jimenez et al. ${ }^{66}$ explored the diversity of endophytic fungi along an altitudinal gradient (400-2900 m) in tropical forests of Costa Rica. They found that the lower the altitude, the higher was the species richness of endophytic fungi; also particular preference to plant host for fungi in higher altitudes was uncommon. Almost $92 \%$ of these isolates were from the class Sordariomycetes. Colletotrichum Corda, Diaporthe Nitschke and Xylaria were dominant at different altitudes since many years.

The diversity of fungal endophytes in Fortunearia sinensis Rehder \& E.H. Wilson growing in mixed evergreen/deciduous broadleaved forest in Jiangsu Province, China was studied ${ }^{67}$. Almost 1436 strains were isolated from the laminae, petioles and twigs of $F$. sinensis that were collected during spring and autumn. These isolates were classified into 33 genera with Alternaria (21.52\%), Fusarium (19.64\%) and Pestalotiopsis (13.16\%) being the dominant ones. The genus Alternaria was commonly found in both seasons. However, Pestalotiopsis and Chaetomium Kunze were more abundant in spring, while Fusarium and Monotospora Corda in autumn. The diversity of endophytic fungi in $F$. sinensis was higher in the petioles than laminae and twigs ${ }^{67}$.

In the Western Ghats, Pestalotiopsis spp. were isolated from 58 tree species from 4 types of forests (dry thorn, dry deciduous, stunted montane evergreen and moist deciduous). The frequency varied from $0.7 \%$ to $41.0 \%$ with regard to forest type and tree host. ITS sequencing determined that 28 of these isolates, which were identified (on the basis of morphology) as Pestalotiopsis, were discovered 
as 2 genera, i.e. Pestalotiopsis and Neopestalotiopsis Maharachch., K.D. Hyde \& Crous. Pestalotiopsis isolates were identified as P. microspora (Speg.) G.C. Zhao \& N. $\mathrm{Li}, P$. vismiae (Petr.) J. Xiang Zhang \& T. Xu, P. menezesiana (Bres. \& Torrend) Bissett, P. parva Maharachch., K.D. Hyde \& Crousand P. theae (Sawada) Steyaert, while Neopestalotiopsis isolates were identified as $N$. cubana Maharachch., K.D. Hyde \& Crous and N. mesopotamica Maharachch., K.D. Hyde \& Crous, N. australis Maharachch., K.D. Hyde \& Crous, N. ellipsospora (Maharachch. \& K.D. Hyde) Maharachch., K.D. Hyde \& Crous, N. piceana Maharachch., K.D. Hyde \& Crous and N. saprophytica (Maharachch. \& K.D. Hyde) Maharachch., K.D. Hyde \& Crous. It was concluded that Pestalotiopsis spp. are not host-specific endophytes and can be found in many different tree species ${ }^{68}$.

Gazis and Chaverii ${ }^{19}$ examined the leaves and stems of wild rubber trees (Hevea brasiliensis Müll. Arg.) that were found in the Amazon basin, Peru. A total of 175 isolates were obtained, resulting in the identification of 58 OTUs. Ascomycota represented $96.6 \%$ of these isolates. Sapwood samples were found to have a higher diversity of endophytes than leaf samples, with Pestalotiopsis aff. Palmarum (Cooke) Steyaert and Trichoderma harzianum Rifai dominating leaf and sapwood samples respectively. The wild rubber trees contained a higher diversity of beneficial fungal species and less potentially pathogenic species than plantation trees. In particular, they found that there were 2.5 times more Trichoderma strains in the wild trees than plantation trees ${ }^{19}$.

It was observed in a study that endophytic fungi from healthy leaves of Theobroma cacao L., which were isolated from several localities, including tropical forest in the Republic of Panama, had restricted the in vitro growth of the three most common cacao pathogens, namely Moniliophthora roreri (Cif.) H.C. Evans, Stalpers, Samson \& Benny (frosty pod rot), Phytophthora palmivora (E.J. Butler) E.J. Butler (black pod rot), and Moniliophthora perniciosa (Stahel) Aime \& Phillips-Mora (witches broom $)^{69}$. It was also found that one Trichoderma isolate had parasitized $M$. roreri. The study shows the potential of using endophytic fungi as biocontrol agents.

\section{Biodegradation capability of fungi}

Fossil fuels are compounds made up of carbon and hydrogen, or hydrocarbons. The variance between different fossil fuels lies in their hydrogen-to-carbon ratio. Crude oils are mainly used to generate electricity, whereas petroleum and natural gas are used to manufacture chemicals, plastics, paints and many other products, while gasoline and diesel fuels are used in transportation. However, fossil fuels are non-renewable and raise severe environmental concerns ${ }^{70}$. Biodegradation of oil can be done by bioremediation, in which the rates of natural bio- degradation of pollutants are increased by adding materials such as fertilizers or microbes into the affected areas. Because fungi use hydrocarbons as their food source, they can be used to degrade oil in the case of an oil spill ${ }^{71}$.

Quite a number of fungi have been isolated from contaminated coastal and marine areas. Several fungi were isolated from beaches in the Gulf of Mexico (Fusarium, Scopulariopsis Bainier and Aspergillus $)^{72}$, coastal areas of the Red Sea in Saudi Arabia [Alternaria alternata (Fr.) Keissl., Aspergillus flavus, A. fumigatus, A. niger, A. ochraceus $\mathrm{K}$. Wilh., A. sydowii (Bainier \& Sartory) Thom \& Church, A. terreus Thom, Penicillium chrysogenum Thom, P. oxalicum Currie \& Thom, P. rugulosum Thom, Scopulariopsis brumptii Salv.-Duval and Ulocladium atrum Preuss $]^{47}$, and a Mediterranean marine site (A. terreus, Trichoderma harzianum and $P$. citreonigrum Dierckx $)^{73}$.

Several fungi (Aspergillus niger, A. ochraceus and Penicillium chrysogenum) were able to degrade six $n$ alkanes (tridecane, tetradecane, pentadecane, hexadecane, heptadecane, octadecane) and crude oil ${ }^{74}$. Fungi can also degrade other types of oil, such as gasoline. Rhizopus arrhizus A. Fisch. was isolated from a gasoline-polluted mangrove swamp in Nigeria ${ }^{11}$. Rhodotorula aurantiaca (Saito) Lodder and Candida ernobii (Lodder \& Kreger) S.A. Mey. \& Yarrow, isolated from Suape Port in Brazil, were able to degrade diesel oil compounds ${ }^{75}$. While other species were able to degrade used engine oil, e.g. Aspergillus flavus, A. niger, Rhodotorula rubra (Schimon) F.C. Harrison and Torulopsis candida Lodder ${ }^{76}$.

Saravanan and Sivakumar ${ }^{77}$ highlighted the potential of marine ecosystem fungi as hydrocarbon bio-degraders by isolating them from coastal deltaic habitat along the east coast (Bay of Bengal) of India. A total of 41 species were enumerated from five different sampling stations with Aspergillus being the most common genus represented by 14 species. This was followed by Cladosporium with five species, Penicillium with six species and Fusarium with three species. Ten fungal species were chosen for qualitative determination of their ability in biodegrading hydrocarbons. Trichoderma viride Pers. had grown well in diesel-added media (24 $\mathrm{mm}$ in colony diameter), whereas Penicillium citrinum Thom in petrol-added media (90 mm colony diameter).

Mohsenzadeh et $a l^{78}$ evaluated fungal strains obtained from an oil refinery in Iran, for their potential in the bioremediation of petroleum-polluted soils. It was shown that all four fungi were resistant to petroleum pollution. Alternaria sp. showed the highest resistance to $10 \%$ petroleum pollution with $47.50 \mathrm{~mm}$ colony diameter compared to the other three fungal strains, Aspergillus terreus $(31.25 \mathrm{~mm})$, Penicilium sp. $(23 \mathrm{~mm})$ and Acremonium sp. $(20.50 \mathrm{~mm})^{78}$. Adekunle and Adeniyi ${ }^{79}$ isolated fungi from Treculia africana Decne. seeds in Nigeria and assessed their hydrocarbon biodegradation capabilities. Six fungi were examined for the study and 
measurements were carried out every five days by assessing the turbidity of the media. Rhizopus sp. Ehrenb. was found to be the best in degrading oil for all oil types used in the study while the least was found to be Penicillium pinophilum Hedgcock.

Aranda et $a l .^{80}$ studied the biodegradation mechanism of isolated fungi from a polluted pond in Granada, Spain. Among the tested samples, ten fungi were identified and screened for degradation capabilities against anthracene, phenanthrene, dibenzothiophene and dibenzofuran, which are common polyaromatic hydrocarbons (PAHs). PAHs are typically present in areas that have been polluted with fuel or oil. Penicillium oxalicum completely degraded anthracene whereas the others were only able to partially degrade it $(8-81 \%)$. The time-course study found that $P$. oxalicum was able to completely degrade anthracene and dibenzothiophene within four days. The other two PAHs were also degraded by the fungi, but at slower rates.

Recently, Shinde et al. ${ }^{81}$ studied fungi isolated from tarballs found in Betul Beach, Goa, India. Tarballs are semi-solids formed from crude oil that might have been spilled onto the ocean. They are able to travel long distances, causing pollution in coastal areas. Eighteen fungi were identified phylogenetically, including Aspergillus sp., Byssochlamys sp. Westling, Monascus sp. Tiegh., Paecilomyces sp., Penicillium sp., Talaromyces sp., Trichoderma sp. and Xylogone sp. Arx \& T. Nilsson. Some of these fungi (from genera Aspergillus, Paecilomyces, Penicillium, Talaromyces and Trichoderma) have been studied for their hydrocarbon degradation capabilities.

Yeasts are classified into two phyla, Ascomycota and Basidiomycota. These microorganisms are also studied for their potential in degrading oil. Several yeast species are known to have efficiently degraded oil compounds such as Candida tropicalis (Castell.) Berkhout in the Gulf of Egypt ${ }^{82}$. Gargouri et al. ${ }^{83}$ reported that C. tropicalis and Trichosporon asahii Akagi ex Sugita, A. Nishikawa \& Shinoda isolated from industrial wastewater could also efficiently degrade petroleum hydrocarbons.

\section{Conclusion}

Fungal biodiversity in both terrestrial and marine habitats is a fascinating area of research for the plethora of potential products for biotechnology and prospects for bioremediation that this kingdom of organisms offers. Fungi are essential components of the soil that contribute to nutrient availability, and support the growth and stability of forest and mangrove ecosystems. Mycorrhizal fungi can enhance nutrient uptake, while endophytic fungi can increase survival capabilities of their host species. Fungi also play an important role in coastal ecosystems, especially those that are able to degrade hydrocarbons. Fungi with these capabilities can be used in bioremediation, to clean up areas that are heavily polluted such as by oil spill. Fungi with their diverse morphology and varied metabolic capacity are promising candidates for mycoremediation. Fungal applications range from the uptake of toxic heavy metals to degradation of textile dyes, pesticides and polycyclic aromatic hydrocarbons. Hence mycoremediation offers a cost-effective and environment-friendly alternative to decontamination of the polluted environment. Understanding metabolic pathways and advanced genomic research will help shed light on the intricate processes of fungal survival, adaptability and remediation strategies. Their non-specific enzyme systems, robust protein machinery, diverse morphology and absorption capacities offer excellent tools for biodegradation of contaminants. It would also be interesting to develop products of mycoremediation for large-scale application. This article may further contribute to the substantial potential offered by fungal diversity in various habitats and their bioremediation potential.

1. Simões, M. F. et al., Soil and rhizosphere associated fungi in gray mangroves (Avicennia marina) from the Red Sea - a metagenomic approach. Genomic. Proteomic. Bioinformat., 2015, 13, 310-320.

2. Behera, B. C., Mishra, R. R. and Thatoi, H. N., Diversity of soil fungi from mangroves of Mahanadi delta, Orissa, India. $J$. Microbiol. Biotechnol. Res., 2012, 2, 375-378.

3. Madavasamy, S. and Panneerselvam, A., Diversity of mycoflora in mangrove soil at Karankadu, Ramanathapuram (dt), east coast of Tamil Nadu, India. Int. J. Curr. Microbiol. Appl. Sci., 2013, 2, 5061.

4. Khalil, A. M. A., El-Sheikh, H. H. and Sultan, M. H., Distribution of fungi in mangrove soil of coastal areas at Nabq and Ras Mohammed protectorates. Int. J. Curr. Microbiol. Appl. Sci., 2013, 2, 264-274.

5. Ramírez-Elías, M. A. et al., Identification of culturable microbial functional groups isolated from the rhizosphere of four species of mangroves and their biotechnological potential. Appl. Soil Ecol., 2014, 82, 1-10.

6. Madavasamy, S. and Panneerselvam, A., Isolation, identification of fungi from Avicennia marina Muthupet mangroves, Thiruvarur Dt. Asian J. Plant Sci. Res., 2012, 2, 452-459.

7. Dufossé, L., Fouillaud, M., Caro, Y., Mapari, S. A. S. and Sutthiwong, N., Filamentous fungi are large-scale producers of pigments and colorants for the food industry. Curr. Opin. Biotechnol., 2014, 26, 56-61.

8. Celestino, J. D. R., de-Carvalho, L. E., Lima, M. D. P., Lima, A. M., Ogusku, M. M. and de-Souza, J. V. B., Bioprospecting of Amazon soil fungi with the potential for pigment production. Process Biochem., 2014, 49, 569-575.

9. Gerngross, T. U., Advances in the production of human therapeutic proteins in yeasts and filamentous fungi. Nature Biotechnol., 2004, 22, 1409-1414.

10. Ghorai, S., Banik, S. P. P., Verma, D., Chowdhury, S., Mukherjee, S. and Khowala, S., Fungal biotechnology in food and feed processing. Food Res. Int., 2009, 42, 577-587.

11. Nwankwegu, A. S. and Onwosi, C. O., Bioremediation of gasoline contaminated agricultural soil by bioaugmentation. Environ. Technol. Innov., 2017, 7, 1-11.

12. Cerniglia, C. E. and Sutherland, J. B., Bioremediation of polycyclic aromatic hydrocarbons by ligninolytic and nonligninolytic fungi. In Fungi in Bioremediation (ed. Gadd, G. M.), Cambridge University Press, UK, 2001, pp. 136-187.

13. Gupta, N., Bihari, K. M. and Sengupta, I., Diversity of arbuscular mycorrhizal fungi in different salinity of mangrove ecosystem of Odisha, India. Adv. Plants Agric. Res., 2016, 3, 1-5. 
14. Sadhana, B., Arbuscular mycorrhizal fungal diversity in coastal region of Manapaadu near Tiruchendur, Tamil Nadu. Int. J. Pure Appl. Biosci., 2015, 3, 226-236.

15. Séne, S. et al., Ectomycorrhizal fungal communities of Coccoloba uvifera (L.) L. mature trees and seedlings in the neotropical coastal forests of Guadeloupe (Lesser Antilles). Mycorrhiza, 2015, 25, 547-559.

16. Tian, X. L., Cao, L. X., Tan, H. M., Zeng, Q. G., Jia, Y. Y., Han, W. Q. and Zhou, S. N., Study of the communities of endophytic fungi and endophytic actinomycetesfrom rice and their antipathogenic activities in vitro. World J. Microbiol. Biotechnol., 2004, 20, 303-309.

17. Wu, B., Tian, J., Bai, C., Xiang, M., Sun, J. and Liu, X., The biogeography of fungal communities in wetland sediments along the Changjiang River and other sites in China. ISME J., 2013, 7, 1299-1309.

18. Gil, S. V., Pastor, S. and March, G. J., Quantitative isolation of biocontrol agents Trichoderma spp., Gliocladium spp. and actinomycetes from soil with culture media. Microbiol. Res. 2009, 164, 196-205.

19. Gazis, R. and Chaverri, P., Diversity of fungal endophytes in leaves and stems of wild rubber trees (Hevea brasiliensis) in Peru. Fungal Ecol., 2010, 3, 240-254.

20. Torres, S. M., Tadych Jr, M., White, J. M. and Bills, G. F., Isolation and identification of fungal endophytes. In Prospects and Applications for Plant-Associated Microbes: A Laboratory Manual Part B: Fungi (eds Pirttillä, A. M. and Sorvari, S.), BBi, Finland, 2011, pp. 153-164.

21. Kjer, J., Debbab, A., Aly, A. H. and Proksch, P., Methods for isolation of marine-derived endophytic fungi and their bioactive secondary products. Nature Protoc., 2010, 5, 479-490.

22. Lu, Y., Chen, C., Chen, H., Zhang, J. and Chen, W., Isolation and identification of endophytic fungi from Actinidia macrosperma and investigation of their bioactivities. Evid.-Based Complement. Altern. Med., 2012, 2012, 1-8.

23. Guo, L. D., Hyde, K. D. and Liew, E. C. W., Identification of endophytic fungi from Livistona chinensis based on morphology and rDNA sequences. New Phytol., 2000, 147, 617-630.

24. Chaverri, P., Gazis, R. O. and Samuels, G. J., Trichoderma amazonicum, a new endophytic species on Hevea brasiliensis and H. guianensis from the Amazon basin. Mycologia, 2011, 103, 139-151.

25. Gilna, V. V. and Khaleel, K. M., Diversity of fungi in mangrove ecosystem. J. Exp. Sci., 2011, 2, 47-48.

26. Choi, Y.-W., Hyde, K. D. and Ho, W. W. H., Single spore isolation of fungi. Fungal Divers., 1999, 3, 29-38.

27. Nayak, S. S., Gonsalves, V. and Nazareth, S. W., Isolation and salt tolerance of halophilic fungi from mangroves and solar salterns in Goa - India. Indian J. Mar. Sci., 2012, 41, 164-172.

28. Selvakumar, V., Panneerselvam, A., Vijayakumar, N., Savery, M. and Thajuddin, N., Diversity of endophytic and rhizosphere soil fungi of Avicennia marina in Maravakadu mangrove forest. IOSR J. Pharm. Biol. Sci., 2014, 9, 24-28.

29. Chaverri, P., Branco-Rocha, F., Jaklitsch, W., Gazis, R., Degenkolb, T. and Samuels, G. J., Systematics of the Trichoderma harzianum species complex and the re-identification of commercial biocontrol strains. Mycologia, 2015, 107, 558-590.

30. Kutateladze, L. Y., Zakariashvili, N. G., Jobava, M. D., Burduli, T. A. and Sadunishvili, T. A., Microscopic fungi spread in different types of soils in Western Georgia. Ann. Agrar. Sci., 2016, 14, 227-232

31. Yang, H., Lü, G., Jiang, H., Shi, D. and Liu, Z., Diversity and distribution of soil micro-fungi along an elevation gradient on the north slope of Changbai Mountain. J. For. Res., 2017, 28, 831839

32. de Paula, M. B. P., Speranza, P., Ohara, A., da Silva, É. B., de Angelis, D. A. and Macedo, G. A., Fungi from Brazilian Savannah and Atlantic rainforest show high antibacterial and antifungal activity. Biocatal. Agric. Biotechnol., 2017, 10, 1-8.

33. Lihan, S., Lin, C. S., Ahmad, I., Sinang, F. M., Hua, N. K. and Sallehin, A. A., Antimicrobial producing microbes isolated from soil samples collected from Nanga Merit Forest in Sarawak, Malaysian Borneo. Eur. J. Exp. Biol., 2014, 4, 494-501.

34. Banakar, S. P., Thippeswamy, B., Thirumalesh, B. V. and Naveenkumar, K. J., Diversity of soil fungi in dry deciduous forest of Bhadra Wildlife Sanctuary, Western Ghats of southern India. J. For. Res., 2012, 23, 631-640.

35. Banakar, S. P. and Thippeswamy, B., Isolation and partial purification of fungal ligninolytic enzymes from the forest soil fungi isolated from Bhadra Wildlife Sanctuary. Front. Biol., 2014, 9, 291-299.

36. Jalajuddin, M., Studies of microbial abundances in mangrove habitats along the Karachi coast. Pak. J. Mar. Sci., 2000, 3, $107-$ 113.

37. Li, J. L., Sun, X., Chen, L. and Guo, L. D., Community structure of endophytic fungi of four mangrove species in southern China. Mycology, 2016, 7, 180-190.

38. Azevedo, E., Caeiro, M. F., Rebelo, R. and Barata, M., Biodiversity and characterization of marine mycota from Portuguese waters. Anim. Biodivers. Conserv., 2011, 34, 205-215.

39. Morrison-Gardiner, S., Dominant fungi from Australian coral reefs. Fungal Divers., 2002, 9, 105-121.

40. Hong, J., Investigation of marine-derived fungal diversity and their exploitable biological activities. Mar. Drugs, 2015, 13, 4137-4155.

41. Zhang, T., Wang, N. F., Zhang, Y. Q., Liu, H. Y. and Yu, L. Y., Diversity and distribution of fungal communities in the marine sediments of Kongsfjorden, Svalbard (High Arctic). Sci. Rep., $2015, \mathbf{5}, 14524$.

42. Andreakis, N. et al., Diversity of marine-derived fungal cultures exposed by DNA barcodes: the algorithm matters. PLoS ONE, 2015, 10, e0136130; doi:10.1371/journal.pone.0136130.

43. Hong, J. H., Jang, S., Heo, Y. M., Min, M., Lee, H., Lee, Y. M., Lee, H. and Kim, J. J., Investigation of marine-derived fungal diversity and their exploitable biological activities. Mar. Drugs, 2015, 13, 4137-4155.

44. Bonugli-Santos, R. C. et al., Marine-derived fungi: diversity of enzymes and biotechnological applications. Front. Microbiol., 2015, 6, 1-15.

45. Beena, K. R., Raviraja, N. S., Arun, A. B. and Sridhar, K. R., Diversity of arbuscular mycorrhizal fungi on the coastal sand dunes of the west coast of India. Curr. Sci., 2000, 79, 14591466.

46. Parveen, S., Lanjewar, S., Sharma, K. and Kutti, U., Isolation of fungi from the surface water of river. J. Exp. Sci., 2011, 2, 58-59.

47. Alwakeel, S. S., Molecular identification of fungi isolated from coastal regions of Red Sea, Jeddah, Saudi Arabia. J. Assoc. Arab Univ. Basic Appl. Sci., 2017, 24, 115-119.

48. Tsuji, M., A catalog of fungi recorded from the vicinity of Syowa Station. Mycoscience, 2018, 59, 319-324.

49. Brundrett, M. C., Understanding the roles of multifunctional mycorrhizal and endophytic fungi. In Microbial Root Endophytes (eds Schulz, B. J. E., Boyle, C. J. C. and Sieber, T. N.), SpringerVerlag, Berlin, 2006, pp. 281-298.

50. Dighton, J., Fungi in Ecosystem Processes, CRC Press, Boca Raton, FL, USA, 2003, p. 437.

51. Balestrini, R. and Lumini, E., Focus on mycorrhizal symbioses. Appl. Soil Ecol., 2018, 123, 299-304.

52. Johnson, N. C. and Gehring, C. A., Mycorrhizas: symbiotic mediators of rhizosphere and ecosystem processes. In The Rhizosphere (eds Cardon, Z. G. and Whitbeck, J. L.), Elsevier, Cambridge, USA, 2007, pp. 73-100.

53. Jia, S., Nakano, T., Hattori, M. and Nara, K., Root-associated fungal communities in three Pyroleae species and their mycobiont 


\section{REVIEW ARTICLE}

sharing with surrounding trees in subalpine coniferous forests on Mount Fuji, Japan. Mycorrhiza, 2017, 27, 733-745.

54. Roy, M., Watthana, S., Stier, A., Richard, F., Vessabutr, S. and Selosse, M. A., Two mycoheterotrophic orchids from Thailand tropical dipterocarpacean forests associate with a broad diversity of ectomycorrhizal fungi. BMC Biol., 2009, 7, 51.

55. de Souza, T. A. F. and Freitas, H., Arbuscular mycorrhizal fungal community assembly in the Brazilian tropical seasonal dry forest. Ecol. Process., 2017, 6, 2-10.

56. Rodríguez-Morelos, V. H., Soto-Estrada, A., Pérez-Moreno, J., Franco-Ramírez, A. and Díaz-Rivera, P., Arbuscular mycorrhizal fungi associated with the rhizosphere of seedlings and mature trees of Swietenia macrophylla (Magnoliophyta: Meliaceae) in Los Tuxtlas, Veracruz, Mexico. Rev. Chil. Hist. Nat., 2014, 87, 110.

57. Lang, C., Seven, J. and Polle, A., Host preferences and differential contributions of deciduous tree species shape mycorrhizal species richness in a mixed Central European forest. Mycorrhiza, 2011, 21, 297-308.

58. D'Souza, J. and Rodrigues, B. F., Seasonal diversity of arbuscular mycorrhizal fungi in mangroves of Goa, India. Int. J. Biodivers., 2013, 2013, 1-7.

59. Brundrett, M. C., Global diversity and importance of mycorrhizal and nonmycorrhizal plants. In Biogeography of Mycorrhizal Symbiosis (ed. Tedersoo, L.), Springer, Cham, Switzerland, 2017, pp. 533-556.

60. Greipsson, S. and El-Mayas, H., Arbuscular mycorrhizae of Leymus arenarius on coastal sands and reclamation sites in Iceland and response to inoculation. Restor. Ecol., 2000, 8, 144150 .

61. Johansen, R. B., Vestberg, M., Burns, B. R., Park, D., Hooker, J. E. and Johnston, P. R., A coastal sand dune in New Zealand reveals high arbuscular mycorrhizal fungal diversity. Symbiosis, 2015, 66, 111-121.

62. Moeller, H. V., Peay, K. G. and Fukami, T., Ectomycorrhizal fungal traits reflect environmental conditions along a coastal California edaphic gradient. FEMS Microbiol. Ecol., 2014, 87, 797-806.

63. White, J. F., Tadych, M., Torres, M. S., Bergen, M. S., Irizarry, I., Chen, Q. and Zambell, C., Endophytic microbes, evolution and diversification of. In Encyclopedia of Evolutionary Biology (ed. Kliman, R. M.), Elsevier, USA, 2016, pp. 505-510.

64. Sun, X. and Guo, L. D., Endophytic fungal diversity: review of traditional and molecular techniques. Mycology, 2012, 3, 65-76.

65. Sanz-Ros, A. V., Müller, M. M., San Martín, R. and Diez, J. J., Fungal endophytic communities on twigs of fast and slow growing Scots pine (Pinus sylvestris L.) in northern Spain. Fungal Biol., 2015, 119, 870-883.

66. Rojas-Jimenez, K., Hernandez, M., Blanco, J., Vargas, L. D., Acosta-Vargas, L. G. and Tamayo, G., Richness of cultivable endophytic fungi along an altitudinal gradient in wet forests of Costa Rica. Fungal Ecol., 2016, 20, 124-131.

67. Wu, Z., Yan, S., Zhou, S., Chen, S. and Yan, S., Diversity of endophytic mycobiota in Fortunearia sinensis. Acta Ecol. Sin., 2014, 34, 160-164

68. Reddy, M. S., Murali, T. S., Suryanarayanan, T. S., Rajulu, M. B. G. and Thirunavukkarasu, N., Pestalotiopsis species occur as generalist endophytes in trees of Western Ghats forests of southern India. Fungal Ecol., 2016, 24, 70-75.

69. Mejía, L. C. et al., Endophytic fungi as biocontrol agents of Theobroma cacao pathogens. Biol. Control, 2008, 46, 4-14.
70. Taylor, H. S., Hydrocarbon chemistry. Ind. Eng. Chem., 1953, 45, $1440-1441$.

71. Krasner, R. I. and Shors, T., The Microbial Challenge: A Public Health Perspective, Jones \& Bartlett Learning, Burlington, NJ, USA, 2014, p. 550.

72. Simister, R. L., Poutasse, C. M., Thurston, A. M., Reeve, J. L., Baker, M. C. and White, H. K., Degradation of oil by fungi isolated from Gulf of Mexico beaches. Mar. Pollut. Bull., 2015, 100, 327-333.

73. Bovio, E. et al., The culturable mycobiota of a Mediterranean marine site after an oil spill: isolation, identification and potential application in bioremediation. Sci. Total Environ., 2017, 576, 310-318.

74. Elshafie, A., AlKindi, A. Y., Al-Busaidi, S., Bakheit, C. and Albahry, S. N., Biodegradation of crude oil and $n$-alkanes by fungi isolated from Oman. Mar. Pollut. Bull., 2007, 54, 1692-1696.

75. Miranda, R. C., Souza, C. S., Gomes, E. B., Lovaglio, R. B., Lopes, C. E. and Sousa, M. F. V., Biodegradation of diesel oil by yeasts isolated from the vicinity of Suape Port in the State of Pernambuco - Brazil. Braz. Arch. Biol. Technol., 2007, 50, 147152.

76. Ahmad, S. A., Sadiya, S. and Alhaji, S. I., Biodegradation of used engine oil by fungi isolated from mechanic workshop soils in Sokoto Metropolis, Nigeria. Sky J. Soil Sci. Environ. Manage., $2015,4,64-69$.

77. Saravanan, R. and Sivakumar, T., Biodiversity and biodegradation potentials of fungi isolated from marine systems of east coast of Tamil Nadu, India. Int. J. Curr. Microbiol. Appl. Sci., 2013, 2, 192-201.

78. Mohsenzadeh, F., Chehregani Rad, A. and Akbari, M., Evaluation of oil removal efficiency and enzymatic activity in some fungal strains for bioremediation of petroleum-polluted soils. Iran. J. Environ. Health Sci. Eng., 2012, 9, 26.

79. Adekunle, A. A. and Adeniyi, A. O., Biodegradation of petroleum oil by fungi isolated from Treculia africana (Decne) seeds in Nigeria. Afr. J. Environ. Sci. Technol., 2015, 9, 126-135.

80. Aranda, E., Godoy, P., Reina, R., Badia-Fabregat, M., Rosell, M., Marco-Urrea, E. and Garcia-Romera, I., Isolation of Ascomycota fungi with capability to transform PAHs: insights into the biodegradation mechanisms of Penicillium oxalicum. Int. Biodeterior. Biodegrad., 2017, 122, 141-150.

81. Shinde, V. L., Meena, R. M. and Shenoy, B. D., Phylogenetic characterization of culturable bacteria and fungi associated with tarballs from Betul beach, Goa, India. Mar. Pollut. Bull., 2018, 128, 593-600.

82. Farag, S. and Soliman, N. A., Biodegradation of crude petroleum oil and environmental pollutants by Candida tropicalis strain. Braz. Arch. Biol. Technol., 2011, 54, 821-830.

83. Gargouri, B., Mhiri, N., Karray, F., Aloui, F. and Sayadi, S., Isolation and characterization of hydrocarbon-degrading yeast strains from petroleum contaminated industrial wastewater. Biomed Res. Int., 2015, 2015, 1-7.

ACKNOWLEDGEMENT. We thank Universiti Brunei Darussalam for providing support and the necessary facilities for this study.

Received 6 September 2018; revised accepted 3 December 2018

doi: $10.18520 / \mathrm{cs} / \mathrm{v} 116 / \mathrm{i} 5 / 733-740$ 